Grażyna Szyling

Uniwersytet Gdański

Iwona Swidlińska

Uniwersytet Gdański

\title{
Dwa wymiary studiowania w opiniach studentów. Rozpoznanie zjawiska
}

\author{
Two dimensions of studying in students' opinion. \\ Recognition of the phenomenon
}

\begin{abstract}
Streszczenie. W tekście przedstawiono wyniki badania opinii studentów na temat studiowania, rozumianego szeroko - jako zjawisko uwarunkowane społecznie i jednostkowo. Charakterystykę pierwszego z nich wyprowadzono z koncepcji merytokratyzmu i dyskusji podejmowanej z jego założeniami, natomiast do zdefiniowania drugiego wykorzystano psychologiczną typologię orientacji na cele uczenia się. W oparciu o model badawczy zbudowano autorski kwestionariusz, a zgromadzone dane poddano analizom korelacyjnym. Uzyskane wyniki potwierdzają występowanie wśród studentów „choroby dyplomu”. Wyraźna jest studencka aprobata dla przyjmowania różnych strategii przetrwania na uczelni i brak jednoznacznego sprzeciwu wobec nieuczciwych zachowań. Wyniki badania nie pozwalają optymistycznie podejść do możliwości szybkiej „zmiany paradygmatycznej” w szkolnictwie wyższym.
\end{abstract}

Słowa kluczowe: studiowanie, merytokratyzm, egalitaryzm, orientacja na cele uczenia się, opinie studentów

Summary. The paper presents results of a study of students' opinions on the issue of studying understood widely, as a socially and individually conditioned phenomenon. A description of the former has been derived from the concept of meritocratism and a discussion undertaken on its premises, whilst for the definition of the latter the psychological typology of orientations to learning aims has been applied. On the basis of the research model adopted an authorial questionnaire has been constructed and the data collected has been subjected to correlation analyses. The data obtain confirms "the diploma sickness". There emerges a student approval for selection of various survival strategies at university and lack of unequivocal objection to dishonest behaviours. The results of the study do not allow for an optimistic approach to the possibility of a rapid "paradigmatic change" in higher education.

Key words: studying, meritocratism, egalitarianism, orientation to learning aims, students' opinions 
Polskę uważa się za jeden $\mathrm{z}$ niewielu krajów przechodzących w ostatnich kilkudziesięciu latach transformację ustrojową, w którym udało się upowszechnić szkolnictwo wyższe i zmniejszyć nierówności w dostępie do niego (Kwiek 2010, s. 287). Jednak raporty z badań wskazują, że dążenie do egalitaryzacji kształcenia akademickiego było w dotychczasowej polskiej polityce oświatowej ograniczane do zwiększania limitów rekrutacji na studia (OEC, 2006). Osiągnięty w ten sposób efekt umasowienia studiów, zwłaszcza licencjackich, jest wiązany z rynkową reorientacją uczelni publicznych i rozwojem niepublicznego szkolnictwa wyższego oraz często niekorzystnymi konsekwencjami tych zjawisk. Znajdują one swój wyraz w obniżaniu jakości kształcenia oraz w utrwalaniu nierównego dostępu do bardziej atrakcyjnych uczelni, form i kierunków studiów (np. Kwiek 2010, s. 288-299; Malewski 2012).

Zmianie społecznego statusu studiowania towarzyszyły działania systemowe dotyczące programów kształcenia, podporządkowanych logice efektów kształcenia (Kraśniewski 2011). Ich wdrożenie przez uczelnie było warunkiem włączenia się w europejską przestrzeń edukacyjną oraz realizowania strategii uczenia się przez całe życie. Przedsięwzięcia te miały zapewnić autonomię programową szkół wyższych i wiarygodność kwalifikacji, a także prowadzić do urzeczywistnienia idei „paradygmatycznej zmiany from teaching to learning" (Sajdak 2013, s. 293), czyli do przeniesienia punktu ciężkości z nauczania na uczenie się. W perspektywie pedagogicznej oznacza to między innymi oczekiwanie od studentów zwiększenia ich aktywności i autonomii poznawczej oraz osobistej odpowiedzialności za kształt własnego wykształcenia. Jednak w praktyce działania te często nie wyszły poza sferę założeń (np. Czerepaniak-Walczak 2013; Sajdak 2013; Szyling 2016).

Przywołane przykłady wyznaczają najszerszy kontekst podjętych badań oraz wskazują, że ocena społecznego i dydaktycznego status quo szkół wyższych nie jest jednoznaczna. Jednak polskie społeczeństwo powszechnie wierzy w wartość i atrakcyjność wyższego wykształcenia, które w ostatnich latach jest coraz częściej postrzegane jako konieczny warunek znalezienia dobrej pracy (CBOS 2017; CBOS 2013a).

W tej publicznej debacie wokół szkolnictwa wyższego wybrzmieć powinna także opinia studentów, dotychczas marginalizowanych badawczo (zob. Kwiek 2010, s. 278-279; Pauluk 2016). Są oni przecież uwikłani w społeczny kontekst kształcenia i warunki stwarzane im przez uczelnie, ale również sami te okoliczności wytwarzają, przyjmując określone postawy wobec studiowania (np. Smużewska i in. 2015; Mikut 2014). Jest to zjawisko ujaw- 
niane także przez andragogów badających doświadczenia edukacyjne (zob. Jurgiel-Aleksander 2013, s 154).

Zarysowane przesłanki uzasadniają wybór celu badań własnych. Jest nim rozpoznanie opinii studentów na temat studiowania, rozumianego jako zjawisko uwarunkowane społecznie i jednostkowo, a więc osadzone w dwóch rodzajach kontekstu.

\section{Dwa wymiary studiowania}

Dla zdefiniowania społecznego wymiaru studiowania kluczowa jest koncepcja merytokratyzmu, której relacje z edukacją wielostronnie przedstawia literatura pedagogiczna (np. Melosik 2003; Gmerek 2003). Podstawowe założenia tego podejścia już wiele lat temu sproblematyzowali twórcy kredencjalizmu (tamże), zaś selekcja edukacyjna oparta na merytokratycznym założeniu o równości szans edukacyjnych zaczęła być z czasem wypierana przez politykę inkluzji, proponującą powszechność dostępu do kształcenia akademickiego (Malewski 2012). Uwzględnienie tych kwestii w koncepcji badawczej jest uzasadnione wpływem, jaki na postawy wobec studiowania wywiera merytokratyzm zredukowany do zdroworozsądkowych przekonań społecznych (Melosik 2003). Badania wskazują, że wyższe wykształcenie jest w Polsce powszechnie traktowane jak formalny wyznacznik sukcesu odniesionego przez jednostkę (CBOS 2013a; CBOS 2017), a przy tym silnie powiązane z oczekiwaniem konkretnych korzyści osobistych (Turowska 2012; CBOS 2013a). Na liście potencjalnych zysków znajdują się: zdobycie pozycji na rynku pracy, rozwijanie wiedzy i zainteresowań, zaspokojenie ambicji, wyższa jakość życia i „lepsza przyszłość” (CBOS 2013).

Zarysowane trendy społeczne i schematy związane ze studiowaniem silnie kształtują przekonania, wchodzące w skład poznawczego komponentu postawy. Jeśli przyjmą one charakter intelektualnego stanu pewności o prawdziwości danego zjawiska, mogą nadawać kierunek wartościowaniu przez jednostkę otaczającej ją rzeczywistości i wytwarzać określony stosunek do przedmiotu postawy. Ten $\mathrm{z}$ kolei pozostaje $\mathrm{w}$ silnych relacjach $\mathrm{z}$ definiowaniem przez daną osobę kategorii sukcesu i źródeł odczuwania satysfakcji (Wojciszke 2002, s. 178-183).

Zgodnie z powyższym założono $\mathrm{w}$ badaniach własnych, że przesłanki decyzji o kontynuowaniu kształcenia w szkole wyższej są zakotwiczone w kontekście społecznym, który nadaje kierunek wartościowaniu studiowania, ale go nie determinuje. 
W ujęcie to wpisuje się także drugi z wymiarów definiujących przedmiot badań. Jest on zorientowany na proces kształcenia i dotyczy zróżnicowania celów uczenia się, jakie mogą przyjmować studenci. $Z$ aspektem społecznym łączy go rola przekonań jednostki, które - skojarzone z celem skłaniają ją do określonego rodzaju wysiłku inwestowanego w jego osiągnięcie (za: Kozłowski 2006, s. 48-49). Uzasadnia to wykorzystanie w koncepcji badawczej klasyfikacji celów uczenia się, opracowanej przez Carol S. Dweck i Elaine $S$ Elliott. Obejmuje ona trzy rodzaje celów: dydaktyczne (learning goals), popisowe (performance goals) i unikowe (work-avoidant goals), których właściwości (za: Brophy 2002; Kozłowski 2006) służą do scharakteryzowania drugiego aspektu kategorii studiowania.

Orientacja na cele dydaktyczne jest najbliższa idei przeniesienia punktu ciężkości w kształceniu akademickim z nauczania na uczenie się i zdaje się kluczowa dla myślenia o kształceniu dorosłych oraz strategii całożyciowego uczenia się (por. Solarczyk-Szwec 2010). Nadrzędną wartością jest w niej pogłębione zainteresowanie przedmiotem studiów oraz świadome rozwijanie przez jednostkę swoich kompetencji.

$\mathrm{Z}$ kolei orientacje na cele popisowe i unikowe są powszechnie wiązane $z$ tradycyjnym nauczaniem i dominującą rolą nauczyciela. Przyjęcie pierwszych z nich sprawia, że student chce czuć się bezpiecznie na zajęciach, dlatego unika wyzwań, co hamuje proces samodzielnego uczenia się. Łączą się $\mathrm{z}$ tą postawą techniki maskowania trudności i sięganie po płytkie strategie poznawcze, które mają ułatwiać uzyskanie wysokich średnich ocen. Natomiast dla jednostek zorientowanych na cele unikowe kluczowe jest ograniczanie wysiłku i czasu wkładanego w uczenie się, dlatego przyjmują one w uczeniu się różne strategie przetrwania (za: Brophy 2002; Kozłowski 2006). Obie te orientacje wytwarzają psychologiczne zaplecze sprzyjające różnym formom ściągania (zob. Kobierski 2006).

\section{Założenia metodologiczne}

Zarysowane ramy pojęciowe kategorii studiowania są podstawą koncepcji badań własnych, której kierunek nadają następujące problemy:

1. Z jakimi społecznymi przekonaniami na temat studiowania studenci identyfikują się najsilniej?

2. Jaki rodzaj orientacji na cele uczenia się studenci uznają za najbliższy sobie? 
3. Czym różnią się opinie o studiowaniu wyrażane przez studentów uniwersytetu i politechniki?

Badanie ma charakter eksploracyjny, a jego zasadnicza część jest realizowana w schemacie przeglądowym, dlatego nie stawia się w nim hipotez, ale wykorzystuje analizy korelacyjne (Konarzewski 2000), co wymaga zachowania ostrożności przy wnioskowaniu. Podstaw do uogólniania wyników nie daje też celowy dobór próby badawczej ( $N=104)$, którą tworzą studenci studiów stacjonarnych pierwszego stopnia: pedagogiki wczesnej edukacji na UG ( $N=50)$ i technologii chemicznej na PG (N=54). Badanie zrealizowano w maju $2017 \mathrm{r}$.

Do gromadzenia danych wykorzystano autorski kwestionariusz ankiety. W jego konstrukcji wyróżniono dwa zasadnicze moduły, każdy złożony z 12 pozycji i przyporządkowany jednemu z wymiarów studiowania. W każdym z modułów wydzielono grupy twierdzeń odpowiadające poszczególnym wskaźnikom, i tak:

1. W zmiennej „społeczne przekonania na temat studiowania” są to: społeczna koncepcja wyższego wykształcenia oraz korzyści związane ze zdobyciem dyplomu.

2. W zmiennej „orientacja na cele uczenia się” podział na 3 części odpowiada 3 rodzajom celów: dydaktycznym, popisowym i unikowym.

Opcje odpowiedzi oparto na skali szacunkowej Likerta. Przyjęto, że liczbowym wskaźnikiem zaakceptowania przez respondentów danego twierdzenia jest średnia $X \geq 3,5$, zaś brak akceptacji wyraża $X \leq 2,35$. Uwzględniono także granice przedziału ufności, odpowiednio: dolna granica przedziału akceptacji $\geq 3,3$; górna granica przedziału braku akceptacji $\leq 2,55$.

Trzeba zastrzec, że kwestionariusza nie można uznać za skalę postaw, ponieważ nie spełnia on warunków standaryzacji (Konarzewski 2000, s.153). Nawet po usunięciu 4 pozycji (po 2 z każdego modułu) najniżej skorelowanych ze średnim wynikiem, alfa Cronbacha jest umiarkowana i wynosi 0,61 .

W związku z powyższym zakłada się, że deklaracje badanych oraz wartościowanie przez nich różnych aspektów studiowania nie muszą być spójne, a pojawiająca się różnorodność może sygnalizować obszary, które należałoby wyjaśnić lub zbadać z innej perspektywy. 


\section{Analiza wyników}

Przed przystąpieniem do bezpośredniej odpowiedzi na pytania badawcze przeanalizowano ogólne wyniki dwóch zasadniczych modułów kwestionariusza.

\section{Tabela 1. Korelacja średnich wyników modułów ze średnimi mynikami kwestionariusza}

\begin{tabular}{lcccc}
\hline $\begin{array}{c}\text { Moduly kwestionariusza } \\
\text { (mymiary studiowania) }\end{array}$ & Średnia & $\begin{array}{c}\text { Współczynnik } \\
\text { Pearsona }\end{array}$ & $\begin{array}{c}\text { determinacji } \\
\text { r2 (\%) }\end{array}$ & $p$ \\
\hline $\begin{array}{l}\text { Społeczne przekonania na temat studiowania } \\
\text { Orientacja na cele uczenia się }\end{array}$ & 3,04 & 0,87 & $75,7 \%$ & $p<0,025$ \\
\hline
\end{tabular}

Źródło: badania własne

Obydwa moduły wysoko korelują ze średnimi wynikami kwestionariusza, wyjaśniając zróżnicowanie ponad $75 \%$ z nich. Z kolei siła wzajemnego związku modułów jest umiarkowana, ale istotna statystycznie $(p<0,001)$ i wynosi $r=0,55$, co wskazuje, że występują między nimi jakieś relacje, ale nie są one oczywiste.

Analizę stopnia identyfikowania się respondentów ze społecznymi przekonaniami na temat studiowania zawiera tab. 2. Szarym kolorem zaznaczono twierdzenia powiązane z merytokratyzmem.

Studenci najsilniej identyfikują się z poglądami typowymi dla potocznie rozumianego merytokratyzmu, które głoszą, że studiowanie jest dla jednostki nobilitacją (1)* i niesie ze sobą obietnicę uzyskiwania w przyszłości wyższych zarobków (12). To drugie twierdzenie wyjaśnia ponad $21 \%$ wyników ogólnych. Niższe natomiast jest prawdopodobieństwo korelacji występujących między wynikiem ogólnym i egalitarnymi przekonaniami o równej wartości wszystkich dyplomów (3) i korzyściach z umasowienia studiów (11). Tylko połowa respondentów sądzi, że umożliwienie studiowania wszystkim chętnym jest stworzeniem im szansy lepszego życia.

* W ten sposób oznaczany jest w artykule numer komentowanej pozycji kwestionariusza ankiety. 
Tabela 2. Identyfikacja studentów ze społecznymi przekonaniami na temat studiowania

\begin{tabular}{|c|c|c|c|c|c|c|c|c|}
\hline & & Przekonania na temat studiowania & 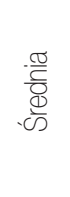 & $\begin{array}{l}\frac{3}{0} \\
\frac{0}{0} \\
\frac{0}{0} \\
\frac{0}{0} \\
\frac{0}{0} \\
\frac{\mathbb{0}}{0 !}\end{array}$ & 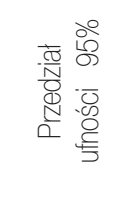 & $\begin{array}{l}\frac{\pi}{\frac{\pi}{\pi}} \\
\frac{\pi}{2}\end{array}$ & 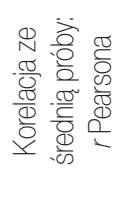 & e \\
\hline \multirow{4}{*}{ 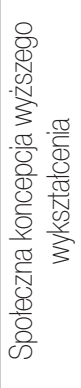 } & 1. & Studiowanie jako nobilitacja & 3,59 & 0,11 & $3,80-3,38$ & 4 & 0,22 & $p<0,001$ \\
\hline & 3. & $\begin{array}{l}\text { Egalitaryzacja studiów jako droga } \\
\text { do ułatwienia kariery }\end{array}$ & 3,38 & 0,12 & $3,60-3,15$ & 4 & 0,49 & $p<0,05$ \\
\hline & 10. & $\begin{array}{l}\text { Potrzeba selekcji w procesie } \\
\text { studiowania }\end{array}$ & 3,37 & 0,10 & $3,56-3,17$ & 4 & 0,20 & $p<0,05$ \\
\hline & 11. & $\begin{array}{l}\text { Masowość studiów jako sposób } \\
\text { wyrównywania szans }\end{array}$ & 3,26 & 1,28 & $3,51-3,01$ & 4 & 0,41 & $p<0,5$ \\
\hline \multirow{6}{*}{ 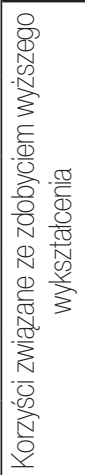 } & 12. & Zapewnienie wysokich zarobków & 3,61 & 0,11 & $3,83-3,41$ & 4 & 0,46 & $p<0,001$ \\
\hline & 9. & $\begin{array}{l}\text { Dyplom studiów jako wartość } \\
\text { sama w sobie }\end{array}$ & 3,38 & 0,11 & $3,59-3,16$ & 4 & 0,26 & $p<0,05$ \\
\hline & 5. & $\begin{array}{l}\text { Przesunięcie w czasie wejścia } \\
\text { w dorosłośc }\end{array}$ & 3,32 & 0,11 & $3,54-3,09$ & 4 & 0,19 & $p<0,25$ \\
\hline & 7. & $\begin{array}{l}\text { Możliwość bycia ekspertem } \\
\text { w danej dziedzinie }\end{array}$ & 2,33 & 0,12 & $2,55-2,10$ & 2 & 0,34 & $p<0,001$ \\
\hline & 17. & Zaspokojenie oczekiwań rodziców & 2,33 & 0,14 & $2,59-2,06$ & 1 & 0,39 & $p<0,001$ \\
\hline & 4. & $\begin{array}{l}\text { Utatwiony dostęp do lepszych } \\
\text { miejsc pracy }\end{array}$ & 1,88 & 0,10 & $2,07-1,70$ & 2 & 0,32 & $p<0,001$ \\
\hline
\end{tabular}

Źródło: badania własne

Większość badanych podważa prawdziwość utylitarnych schematów, które wiążą ukończenie studiów z byciem ekspertem w danej dziedzinie (7) oraz spełnieniem w przyszłości wymagań rynku pracy (4). Obie te pozycje umiarkowanie dodatnio korelują ze średnimi wynikami kwestionariusza, natomiast żadne znaczące relacje statystyczne nie występują między nimi a dosyć zdecydowanym oczekiwaniem przez studentów korzyści finansowych wynikających z posiadania dyplomu szkoły wyższej (12). Ta ostatnia pozycja kwestionariusza słabo, ale dodatnio koreluje z przekonaniem, że dyplom jest wartością autoteliczną (9). 
Deklaracje badanych uzupełnia ich wstrzemięźliwa aprobata dla merytokratycznej selekcji zachodzącej podczas uczenia się w takiej szkole wyższej, która stawia studentom wysokie wymagania (10), ale bardzo niska korelacja nie pozwala powiązać tego twierdzenia z innymi opiniami wyrażonymi w tym module. Społeczny wymiar studiowania uzupełniają: ostrożna akceptacja (54\%) dla twierdzenia, że studiowanie jest wyborem podyktowanym brakiem pomysłu na własne życie (5), oraz równie umiarkowane odrzucenie (57\%) sugestii, że można podjąć studia, by nie zawieść oczekiwań rodziców (17).

Bardziej spójnego obrazu przedstawionych powyżej opinii badanych studentów dostarcza analiza grup twierdzeń przyporządkowanych do wskaźników (tab. 3).

Tabela 3. Identyfikacja studentów ze społecznymi przekonaniami na temat studiowania. Uporządkowanie wg wskaźników

\begin{tabular}{|c|c|c|c|c|c|}
\hline & $\begin{array}{l}\text { Przekonania na temat studiowania: } \\
\text { grupy wskaźników }\end{array}$ & Średnia & $\begin{array}{c}\text { Korelacja ze } \\
\text { średnią próby: } \\
\text { rPearsona }\end{array}$ & $\begin{array}{c}\text { Współ- } \\
\text { czynnik } \\
\text { determinacij } \\
\text { r2 (\%) }\end{array}$ & $p$ \\
\hline \multirow[t]{3}{*}{1.} & $\begin{array}{l}\text { Społeczna koncepcja wyższego wykształcenia, } \\
\text { w tym: }\end{array}$ & 3,40 & 0,62 & 0,38 & $p<0,001$ \\
\hline & 1.A. merytokratyczna selekcja $(1,10)$ & 3,48 & 0,50 & 0,25 & $p<0,001$ \\
\hline & egalitaryzm $(3,11)$ & 3,31 & 0,45 & 0,20 & $p<0,05$ \\
\hline 2. & $\begin{array}{l}\text { Korzyści związane ze zdobyciem wyższego } \\
\text { wykształcenia, w tym: }\end{array}$ & 2,81 & 0,68 & 0,46 & $p<0,001$ \\
\hline & $\begin{array}{ll}\text { 2.A. } & \text { korzyści wpisane w koncepcję merytokra- } \\
\text { tyzmu }(4,7,12)\end{array}$ & 2,61 & 0,58 & 0,34 & $p<0,001$ \\
\hline & inne korzyści $(5,9,17)$ & 3,01 & 0,47 & 0,22 & $p<0,005$ \\
\hline
\end{tabular}

Źródło: badania własne

Współczynnik determinacji wskazuje, że z wynikami ogólnymi silniej korelują oczekiwane korzyści związane $z$ ukończeniem uczelni niż przekonania społeczne na temat roli wyższego wykształcenia. $Z$ kolei z analizy średnich wyników modułów wynika, że badani nie różnicują wyraźnie podejścia merytokratycznego i egalitarnego, oba umiarkowanie akceptując. Bardziej krytycznie podchodzą zaś do społecznego lub rynkowego uznania dla ich merytorycznych kompetencji, a największe nadzieje wiążą z wyższymi zarobkami i autoteliczną wartością dyplomu. 
Drugi wymiar studiowania jest wyznaczany w niniejszych badaniach przez orientacje na cele uczenia się (tab. 4).

Tabela 4. Akceptowanie przez studentów rodzajów orientacji na cele uczenia się

\begin{tabular}{|c|c|c|c|c|c|c|c|c|}
\hline & & Orientacja na cele uczenia się & 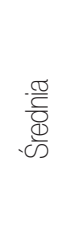 & 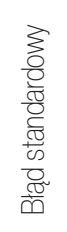 & 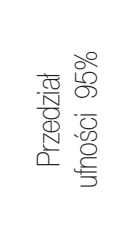 & $\frac{\frac{\pi}{\frac{\pi}{0}}}{\frac{\pi}{8}}$ & 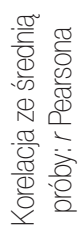 & e \\
\hline \multirow{3}{*}{ 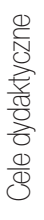 } & 14. & Uczenie się jako pokonywanie trudności & 3,91 & 0,09 & $4,09-3,74$ & 4 & 0,23 & $p<0,001$ \\
\hline & 22. & $\begin{array}{l}\text { Gotowość proszenia o pomoc prowadzą- } \\
\text { cego zajęcia }\end{array}$ & 3,61 & 0,11 & $3,83-3,39$ & 4 & 0,39 & $p<0,001$ \\
\hline & 23. & $\begin{array}{l}\text { Podejmowanie na zajęciach dyskusji } \\
\text { z pracownikiem naukowym }\end{array}$ & 3,17 & 0,12 & $3,41-2,93$ & 4,2 & 0,15 & $p>0,9$ \\
\hline \multirow{4}{*}{$\begin{array}{l}\frac{0}{3} \\
\frac{0}{0} \\
\frac{\infty}{8} \\
\frac{8}{8} \\
\frac{0}{0} \\
0\end{array}$} & 19. & $\begin{array}{l}\text { Bezrefleksyjne wykonywanie poleceń } \\
\text { prowadzącego zajęcia }\end{array}$ & 3,30 & 0,12 & $3,53-3,07$ & 4 & 0,47 & $p<0,25$ \\
\hline & 18. & Nastawienie na bezbłędność & 3,16 & 0,12 & $3,41-2,92$ & 4 & 0,47 & $p>0,99$ \\
\hline & 24. & $\begin{array}{l}\text { Przyzwolenie na ściąganie w wyjątkowych } \\
\text { sytuacjach }\end{array}$ & 2,98 & 0,14 & $3,25-2,71$ & 3,1 & 0,37 & $p<0,1$ \\
\hline & 20. & Zwracanie na siebie uwagi na zajęciach & 2,75 & 0,12 & $2,98-2,52$ & 2 & 0,55 & $p<0,001$ \\
\hline \multirow{3}{*}{$\begin{array}{l}\frac{0}{3} \\
\frac{0}{2} \\
\overline{5} \\
\frac{0}{0} \\
0 \\
0\end{array}$} & 21. & Maskowanie na zajęciach braku wiedzy & 3,83 & 0,10 & $4,02-3,63$ & 4 & 0,28 & $p<0,001$ \\
\hline & 13. & $\begin{array}{l}\text { Podporządkowanie się wykładowcom } \\
\text { w celu zyskania ułatwień }\end{array}$ & 3,67 & 0,11 & $3,88-3,46$ & 4 & 0,32 & $p<0,001$ \\
\hline & & $\begin{array}{l}\text { Ściaganie traktowane jak ułatwienie } \\
\text { uczenia się }\end{array}$ & 2,33 & 0,11 & $2,54-2,11$ & 2 & 0,37 & $p<0,001$ \\
\hline
\end{tabular}

Żródło: badania własne

Najwyższy stopień akceptacji ( $80 \%)$ w analizowanym module i w całym kwestionariuszu uzyskało twierdzenie $\mathrm{nr}$ 14, kluczowe dla orientacji na cele dydaktyczne. Odwołuje się ono do schematu łączącego wartościowe uczenie się „czegoś nowego” $\mathrm{z}$ wykonywaniem trudnych zadań. Jednak znaczna część respondentów tylko deklaratywnie aprobuje to przekonanie, na co wskazują wyniki analiz korelacyjnych $(p<0,001)$, z których na szczególną uwagę zasługują słabo zaznaczone ujemne korelacje z poziomem aprobaty dla ściągania (16 i 24) i umiarkowana dodatnia korelacja $(r=0,41) \mathrm{z}$ akceptacją dla wysokich wymagań stawianych studentom przez uczelnie (10). 
Wniosku, że tylko niewielka grupa badanych jest gotowa samodzielnie sprostać wysokim wymaganiom w trosce o jakość własnego wykształcenia, znacząco nie zmieniają wyniki dwóch pozostałych pozycji analizowanego modułu. Respondenci wysoko akceptują ( 68\%) zwracanie się o pomoc nauczyciela akademickiego w sytuacji problemów merytorycznych (22), ale ze względu na ujawnioną w badaniu słabość narzędzia może być to odczytane bądź w kategoriach wytrwałości w rozwijaniu kompetencji, bądź jako dążenie do przerzucenia trudności w uczeniu się na prowadzącego zajęcia (zob. Karabenick 2004).

Z kolei sytuacja prezentowania podczas zajęć odmiennego zdania niż wyrażane przez nauczyciela (23) silnie polaryzuje opinie respondentów, a przy tym słabo ujemnie koreluje $\mathrm{z}$ poziomem akceptowania przez nich przejawów postaw konformistycznych (19 i 13). Ponadto badani studenci wysoko aprobują (80\%) strategie stwarzania pozorów merytorycznego uczestniczenia w zajęciach (21).

Przeprowadzone analizy wskazują, że trudno na podstawie zgromadzonych danych stworzyć spójny obraz opinii badanych studentów na temat aprobowanych przez nich orientacji na cele uczenia się (zob. też tab. 5).

Tabela 5. Akceptowanie przez studentów rodzajów orientacji na cele uczenia się. Uporządkowanie wg wskaźników

\begin{tabular}{lcccc}
\hline $\begin{array}{c}\text { Orientacja na cele uczenia się: } \\
\text { grupy wskaźników }\end{array}$ & $\begin{array}{c}\text { Śred- } \\
\text { nia }\end{array}$ & $\begin{array}{c}\text { Korelacja ze średnią } \\
\text { próby: r Pearsona }\end{array}$ & $\begin{array}{c}\text { Współczynnik deter- } \\
\text { minacji r2 (\%) }\end{array}$ & $p$ \\
\hline 1. Cele dydaktyczne & 3,56 & 0,35 & 12,25 & $p<0,001$ \\
2. Cele popisowe & 3,05 & 0,75 & 56,25 & $p<0,1$ \\
3. Cele unikowe & 3,28 & 0,51 & 26,01 & $p<0,1$ \\
\hline
\end{tabular}

Źródło: badania własne

Wartość średniej wyników dla celów dydaktycznych problematyzują omówione powyżej analizy korelacyjne oraz słabo zaznaczona korelacja modułu z wynikami ogólnymi kwestionariusza. $Z$ kolei orientacje na cele popisowe i unikowe, silniej korelują z wynikami ogólnymi, ale są obarczone znacznym błędem szacowania.

Do analiz niewiele wnosi zbadanie relacji między opiniami studentów uniwersytetu i politechniki. Obliczony dla tych grup współczynnik korelacji rangowej Spearmana $r_{s}=0,91$. 


\section{Dyskusja}

Nie można zasadnie przyjąć, że postawy lub wchodzące w ich skład przekonania znajdują proste odzwierciedlenie $\mathrm{w}$ postępowaniu jednostki, ponieważ między nimi i działaniem pośredniczy wiele czynników sytuacyjnych (Wojciszke 2002, s. 202-206). Jest to kolejna przesłanka, poza już wymienionymi, nakazująca zachowanie ostrożności przy odczytywaniu wyników.

Opinie studentów w przeprowadzonych badaniach są skupione wokół średniej, lecz wiąże się to raczej z rzadkim wybieraniem skrajnych opcji skali odpowiedzi ( 26,6\%) niż spójnością wewnętrzną deklaracji. Zaskakująco wysoki i istotny statystycznie jest współczynnik korelacji między deklaracjami studentów uniwersytetu i politechniki, co jednak odbiega od danych z diagnoz CBOS (2013), które wskazują, że połowa objętych nimi respondentów widzi większe możliwości zatrudnienia po ukończeniu studiów technicznych niż humanistycznych. Być może źródłem wyników uzyskanych w badaniach własnych jest specyficzny dobór próby: studenci pedagogiki wczesnej edukacji mają jasno określony zakres kompetencji zawodowych oraz możliwości zatrudnienia absolwentów.

Z kolei analizy korelacyjne, odwołujące się do założeń teoretycznych badania, ujawniają niespójności w deklaracjach respondentów, ale jest to charakterystyczne dla opinii wyrażanych o złożonych zjawiskach, ważnych emocjonalnie dla badanych (Marody 1976, s. 20-21).

W wymiarze społecznym studenci najsilniej identyfikują się z przekonaniami, że studiowanie jest dla jednostki swoistą nobilitacją, a zarazem niesie ze sobą obietnicę uzyskania w przyszłości wyższych zarobków. Ta pierwsza opinia dla wielu respondentów nie jest przeszkodą w akceptowaniu egalitarnych rozwiązań w szkolnictwie wyższym, co jest zbieżne z wynikami najnowszych badań CBOS (2017).

Z wnioskami z diagnoz społecznych (CBOS 2017; CBOS 2013) korespondują w badaniach własnych także wartości, jakie studenci przypisują dyplomowi szkoły wyższej. Wysoko oceniają oni jego wartość, niezależnie od jego bezpośredniej przydatności do rodzaju wykonywanej pracy. Zdają się przy tym wątpić w jego znaczenie merytoryczne i rynkowe (por. Pauluk 2016, s. 192). W takim ujęciu ukończenie studiów jest postrzegane bardziej jak konieczność niż gwarancja sukcesu życiowego czy uzyskania innych nagród społecznych niż wysokość zarobków (zob. CBOS 2017; CBOS 2013; por. Turowska 2012). Ten kontekst może wyjaśniać, dlaczego znacznej grupie badanych niezbyt zależy na tym, by uczelnia stawiała im wysokie wymagania (por. Mikut 2014; Pauluk 2016), zwłaszcza że połowa z nich akceptu- 
je pogląd, że studiowanie bywa wyborem podyktowanym brakiem pomysłu na własne życie (por. CBOS 2013), a zbliżona wielkością, choć nie tożsama grupa nie odrzuca sugestii, że można podjąć studia, by nie zawieść oczekiwań rodziców.

Poziom identyfikacji studentów ze społecznymi przekonaniami na temat studiowania umiarkowanie dodatnio i z wysokim prawdopodobieństwem koreluje $z$ aprobowanymi przez nich celami uczenia się, co pozwala ostrożnie wnioskować, że silnie zarysowane w pierwszym module kwestionariusza nastawienie respondentów na studiowanie dla uzyskania dyplomu nie sprzyja wybieraniu orientacji na cele dydaktyczne (zob. Brophy 2002; por. Kozłowski 2006). Tezy tej nie podważa wysoka średnia akceptacja respondentów dla twierdzeń związanych z tą grupą celów. Analizy statystyczne wykazały bowiem, że większość badanych nie dostrzega sprzeczności między przypisywaniem wysokiej wartości trudnym zadaniom $\mathrm{w}$ procesie uczenia się i aprobatą dla przyjmowania strategii przetrwania. Respondenci nie wartościują również jednoznacznie negatywnie przejawów ściągania czy nieuczciwego zapewniania sobie pozytywnych ocen (por. Pauluk 2016, s. 193). Można zatem uznać, że tylko niewielka grupa studiujących jest gotowa samodzielnie stawić czoła wysokim wymaganiom, troszcząc się o merytoryczną jakość własnego wykształcenia (por. Mikut 2014; Smużewska i in. 2015).

Charakterystyczne dla wybierania przez respondentów orientacji na cele uczenia się jest większe zróżnicowanie opinii niż w kwestii identyfikowania się z przekonaniami społecznymi. Uwagę zwraca zwłaszcza dosyć wyraźna aprobata studentów dla działań i wartości o charakterze konformistycznym. Zarówno ten wniosek, jak i poprzednie współbrzmią z wynikami niedawnego badania potocznych doświadczeń studentów (Pauluk 2016). Odmienność koncepcji metodologicznych nie pozwala porównywać wprost danych z badań własnych i zgromadzonych przez Dorotę Pauluk (2016), ale podobieństwa zdają się oczywiste i na zasadzie triangulacji potwierdzają trafność konkluzji sformułowanych w obu badaniach.

\section{Wnioski}

Wnioski z badań, zgodnie z organizującą je koncepcją, odnoszą się do dwóch wymiarów studiowania, zaś towarzysząca im interpretacja wykorzystuje tropy przywołane w początkowych częściach niniejszego tekstu. 
W swoich opiniach dotyczących przekonań społecznych na temat studiowania badani nie wartościowali odmiennie - opozycyjnych w gruncie rzeczy - założeń egalitarnych i wywiedzionych z merytokratyzmu, co może się wiązać z „niewidocznym”, acz powszechnym oddziaływaniem potocznie rozumianego merytokratyzmu na poglądy dotyczące edukacji (Melosik 2003; por.: Malewski 2012). Odpowiedzi respondentów potwierdzają również swoiste zainfekowanie studentów "chorobą dyplomu” (Gmerek 2003), co nie pozostaje bez znaczenia dla wybierania przez nich strategii studiowania.

Zgromadzone w badaniach opinie dotyczące tego drugiego wymiaru kształcenia w szkole wyższej nie pozwalają optymistycznie podejść do możliwości szybkiej „zmiany paradygmatycznej” czy powszechnego zwiększenia autonomii poznawczej studentów w procesie uczenia się (por. Czerepaniak-Walczak 2013; Sajdak 2013; Pauluk 2016; Szyling 2016). Szczególnie niepokojąca zdaje się studencka aprobata dla różnych przejawów strategii przetrwania i brak wyraźnego sprzeciwu wobec nieuczciwych zachowań, identyfikowanych z szeroko rozumianym ściąganiem.

$\mathrm{Na}$ obraz studiowania, postrzegany przez pryzmat opinii studentów, składają się wątki będące zaprzeczeniem wielu właściwości uznawanych przez andragogów za niezbędne warunki uczenia się dorosłych (zob. Solarczyk-Szwec 2010). Nie można więc uznać, że niesie on ze sobą jednoznacznie pozytywny bagaż doświadczeń edukacyjnych, tworzących silne rusztowanie dla postawy sprzyjającej uczeniu się przez całe życie. Dociekanie źródeł takiego stanu rzeczy pozostaje zagadnieniem do podjęcia w kolejnych eksploracjach.

\section{Bibliografia}

Brophy J. (2002), Motywowanie uczniów do nauki, tłum. K. Kruszewski, Wydawnictwo Naukowe PWN, Warszawa.

CBOS (2017), Czy warto się kształcić? Komunikat z badań, 62, Warszawa.

Czerepaniak-Walczak M. (2013), Autonomia w kolorze sepii w inkrustowanej ramie KRK. O procedurach i treściach zmiany w edukacji akademickiej, [w:] M. Czerepaniak-Walczak (red.), Fabryki dyplomów czy universitas? O „nadwiślańskiej” wersji przemian w edukacji akademickiej, Oficyna Wydawnicza „Impuls”, Kraków, s. 29-56.

Gmerek T. (2003), Młodzież i dyplom akademicki. Społeczne konstrukcje sukcesu życiowego, [w:] T. Gmerek (red.), Edukacja i stratyfikacja społeczna, Wolumin, Poznań, s. 37-52. 
Jurgiel-Aleksander A. (2013), Doświadczenie edukacyjne w perspektywie andragogicznej. Studium biograficzno-fenomenograficzne, Wydawnictwo Uniwersytetu Gdańskiego, Gdańsk.

Karabenick S.A. (2004), Perceived Achievement Goal Structure and College Student Help Seeking, „Journal of Educational Psychology”, 96(3), s. 569-581.

Kobierski K. (2006), Ściqganie w szkole. Raport z badań. Oficyna Wydawnicza „Impuls", Kraków.

Konarzewski K. (2000), Jak uprawiać badania oświatowe? Metodologia praktyczna, WSiP, Warszawa.

Kozłowski W. (2006), Cele i osiagnnięcia w uczeniu się, Wydawnictwo SGGW, Warszawa.

Kwiek M. (2010), Transformacje uniwersytetu. Zmiany instytucjonalne i ewolucyjne polityki edukacyjnej w Europie, Wydawnictwo Naukowe UAM, Poznań.

Malewski M. (2012), Edukacja akademicka w pułapce pozornego egalitaryzmu, „Pedagogika Szkoły Wyższej”, 1, s. 17-42.

Marody M. (1976), Sens teoretyczny a sens empiryczny pojęcia postawy. Analiza metodologiczna zasad doboru wskaźników w badaniach nad postawami, PWN, Warszawa.

Melosik Z. (2003), Edukacja uniwersytecka i stratyfikacja społeczna, [w:] T. Gmerek (red.), Edukacja i stratyfikacja społeczna, Wolumin, Poznań, s. 53-78.

Mikut M. (2014), Zaangażowanie w studiowanie czy pozorowanie?, „Pedagogika Szkoły Wyższej”, 1, s. 105-122.

Pauluk D. (2016), Wspótczesny uniwersytet w potocznych doświadczeniach studentów, „Teraźniejszość - Człowiek - Edukacja”, t. 19, 3(75), s. 183-196.

Sajdak A. (2013), Paradygmaty kształcenia studentów i wspierania rozwoju nauczycieli akademickich. Teoretyczne podstawy dydaktyki akademickiej, Oficyna Wydawnicza „Impuls”, Kraków.

Smużewska, M., Wasilewski, K., Antonowicz D. (2015), Niepowodzenia w studiowaniu z perspektywy uczelni i studentów, „Edukacja”, 4(135), s. 130-146.

Solarczyk-Szwec H. (2010), Dorośli uczą się inaczej? W poszukiwaniu kategorii pojęciowych opisujących proces uczenia się dorostych, „Teraźniejszość - Człowiek - Edukacja”, 1(49), s. 51-60.

Turowska, A. (2012), Korzyść, krzywda, zagrożenie czy wyzwanie - percepcja studiów wśród kończących warszawskie uczelnie publiczne, „Kwartalnik Pedagogiczny”, 2(224), s. 163-171.

Wojciszke B. (2002), Człowiek wśród ludzi. Zarys psychologii społecznej, Wydawnictwo Naukowe „Scholar”, Warszawa.

\section{Netografia}

CBOS (2013), Studia wyższe - dla kogo, po co i z jakim skutkiem? Komunikat z badań BS/92/2013, dostępny na: http://www.cbos.pl/ SPISKOM. POL/2013/K_096_13.PDF (otwarty: 06.05.2017) 
CBOS (2013a), Wyksztatcenie ma znaczenie? Komunikat z badań BS/96/2013, dostępny na: http://www.cbos.pl/SPISKOM.POL/2013/K_096_13.PDF (otwarty: 06.05.2017)

Kraśniewski A. (2011), Jak przygotowywać programy kształcenia zgodnie z wymaganiami wynikającymi z Krajowych Ram Kwalifikacji dla Szkolnictwa Wyższego?, dostępny na: http://www.procesbolonski.uw.edu.pl/dane/publikacja_ MNISW_AK_111103.pdf (otwarty: 10.07.2015)

OECD Thematic Review of Tertiary Education. Country Background Report for Poland, OECD 2006, dostępny na: https://www.oecd.org/poland/37231744.pdf (otwarty: 30.08.2017)

Szyling G. (2016), Egzaminowanie w szkole wyższej: między (nie)oczywistością znaczeń i złudzeniami zmiany, „Forum Oświatowe”, Vol. 28, 2(56), s. 161-183, dostępny na: http://forumoswiatowe.pl/index.php/czasopismo/article/view/ /448 (otwarty: 31.08.2017) 